\title{
КОНСТИТУЦІЙНЕ ПРАВО
}

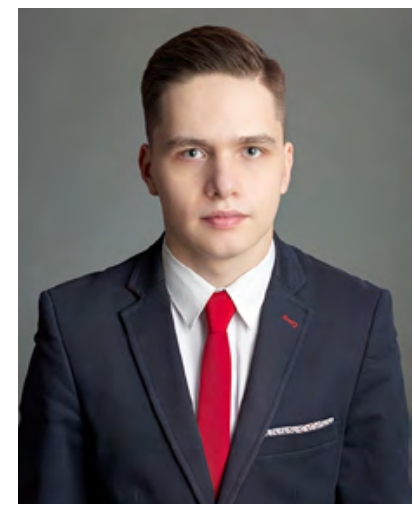

\author{
Аньрій Іркмієнко, \\ науковий співробітник \\ Науково-Аослінного інституту морського і \\ космічного права
}

ORCID: 0000-0002-5689-2226

https://doi.org/10.32782/2306-9082/2021-42-1

УдК 342.5

\section{Процедура атраго в Конституційному суді Іспанії: досвід для України}

Постановка проблеми. Будьякий громадянин Іспанії має право вимагати захисту свобод і прав, визнаних у ст. ст. 14-29 Конституції Іспанії (ст. 53.2), за допомогою швидкого i спрощеного провадження в судах загальної юрисдикції та, в разі потреби, за допомогою заяви особистого клопотання про захист (recurso de amparo) до Конституційного Суду (далі - КС) (ст. 161.1 (в)) [5]. Також у конституційному судочинстві здійснюється захист у разі відмови від військової служби за мотивами переконань або віросповідання, передбаченому в ст. 30 Конституції (ст. 41.1 Закону Іспаніїпро КС) [5].

Процедура конституційного захисту регулюється розділом IX Конституції і розділом III Органічного закону про КС від 3 жовтня 1979 року 3 подальшими змінами.

Аналіз останніх досліджень i публікацій. У сучасній конституційноправовій науці активно обговорюється питання запровадження в системі конституційного судочинства України інституту конституційної скарги як демократичного механізму захисту конституційних прав людини від посягань із боку держави та їі посадових осіб. Ця проблема неодмінно потрапляє в поле зору і під час офіційних заходів, які проходять у стінах Конституційного Суду України, та має підтримку з боку визнаних іноземних експертів. Ця та інші переваги інституту конституційної скарги зумовлюють виключну актуальність вітчизняних досліджень, спрямованих на ретельне вивчення іiі різних моделей. Серед останніх найбільший інтерес становлять класичні взірці конституційної скарги, які були запозичені іншими країнами різних регіонів світу у процесі вдосконалення їх конституційної юстиції. Такі класичні моделі конституційної скарги сформувались у західноєвропейських країнах традиційної демократії (Австрії, Бельгіï, Іспанії, Федеративній Республіці. Німеччині, Швейцарії та деяких ін.). Однак, незважаючи на зростаючу кількість публікацій, присвячених проблематиці конституційної скарги, досвід цих країн практично не досліджено на рівні фахової літератури. 
Мета статті полягає в дослідженні процедурі amparo в конституційному суді Іспанії.

Виклад основного матеріалу дослідження. Право на звернення до КС $з$ клопотанням про захист ампаро надано будь-якій фізичній або юридичній особі, захиснику народу і прокуратурі (ст. 162.1 (в) Конституції) [5]. Якщо заява виходить від омбудсмена або прокуратури, то палата КС, до відання якої належить розгляд справи, сповіщає про це відомих їй осіб, яких це звернення може торкнутися, та повідомляє про нього в «Офіційному віснику держави» (ст. 46.2).

Іноземні громадяни також мають право вимагати захисту в КС. Як приклад можна вказати рішення КС від 12 лютого 1996 р. Заявник, громадянин Перу, якому було відмовлено в наданні політичного притулку, звернувся до відповідних органів із клопотанням про звільнення від візових формальностей. Стосовно нього було розпочато процедуру висилки. Через якийсь час заявник з'явився в поліцію, щоб з'ясувати, на якій стадії знаходиться розгляд його клопотання. Його затримали 3 метою висилки згідно з адміністративним рішенням, про яке він був тут же повідомлений [1;2].

Заявник подав скаргу про habeas corpus, яка була відхилена. У зверненні в КС заявник посилався на порушення права на свободу і ефективний судовий захист (ст. 17, 24.1 Конституціï). КС дійшов висновку, що суд мав оцінити з позиції законності наслідки як звільнення заявника від візових формальностей, так і затримки в повідомленні заявника про висилку; в результаті суд мав визнати скаргу про habeas corpus допустимою i розглянути їі, дотримуючись при цьому всіх гарантій, передбачених для подібного провадження, в тому числі заслуховування зацікавленої особи [7; 8].

Фізичні та юридичні особи, які беруть участь у справі як сторони чи треті особи, мають доручити своє представництво в КС судового повіреному і адвокату (ст. 81) [5]. Вимога не поширюється на громадян, які мають вищу юридичну освіту.

Підстави звернення з клопотанням про захист обмежені. У більшості держав категорія природних прав збереглася на рівні доктринальних розробок, а в практиці КС поступилася місцем позитивістському трактуванні прав і свобод. Тобто вони діють тільки в тому обсязі, в якому гарантуються конституцією і законами. Така позиція характерна і для Іспанії [3]. Йдеться про порушення основних прав в їх класичному розумінні, тобто за винятком економічних і соціальних, у тому числі права власності [11].

У практиці Європейського суду з прав людини зустрічаються справи за скаргами громадян Іспанії про втручання в їх зазначені права [9]. Так, цей Суд у рішенні від 23 червня 1993 р. констатував, що в Іспанії відсутній прямий доступ фізичних осіб до КС для оскарження втручання в їхнє право власності, є тільки непрямий - через суди загальної юрисдикції [8]. В останньому випадку сторони позбавлені права на змагальний характер розгляду в КС, що є порушенням Європейської конвенції про захист прав людини i основних свобод (п. 70 рішення).

Серед прав, до захисту яких вдаються найчастіше, можна назвати рівність (ст. 14 Конституції), право на життя, фізичну і моральну цілісність (ст. 15), свободу ідеології і віросповідання (ст. 16), право на свободу та безпеку (ст. 17), на процедуру habeas corpus (п. 4 ст. 17) [5], на честь, репутацію, особисту і сімейну таємницю, недоторканність житла, таємницю комунікацій (ст. 18), на вибір місця проживання i свободу пересування (ст. 19) [5], вирази і поширення поглядів, ідей і думок, викладання, право на літературний, художній, науковий і технічна творчість, інформацію 
(ст. 20), мирні зібрання (ст. 21), об’єднання (ст. 22), право брати участь в громадських справах (ст. 23), права в області правосуддя (ст.ст. 24-26), право на освіту (ст. 27), страйк, право вступати в профспілки (ст. 28), звертатися з петиціями (ст. 29).

На думку іспанських учених, ця система обмеження конституційного захисту далека від досконалості. Конституційне прецедентне право дещо розширює об’єкти цього захисту: в рідкісних, але особливих випадках КС пов’язує справи, що не мають відношення до згаданих статей, із правами, закріпленими в них, і здійснює процедуру ампаро [9;10]. Наприклад, положення про основи судочинства було пов’язано з ефективним судовим захистом або право на свободу політичних партій - із правом асоціацій [4; 7].

Можна зазначити, що як на підставу клопотання про захист часто посилаються на порушення принципу рівності (23\% скарг) або права на ефективний судовий захист (66\%). Наступний приклад це ілюструє, але цікавий він також тим, що в процесі розгляду клопотання про захист однієї особи КС, крім того, оцінює права і обов’язки інших осіб (рішення від 17 січня 1994р.). У розглянутій справу (звичайний) суд прийняв відмову відповідача піддатися гематологічній експертизі, хоча інші докази, будучи достатніми для обгрунтування позову про встановлення батьківства, були недостатні для доказу батьківства. Отже, це судове рішення порушує процесуальні права позивача (ст. 24.1 Конституції), оскільки тягар доведення лягає на нього. КС скасував оскаржуване рішення суду.

КС визнав, що експертиза не порушує права на фізичну недоторканність i недоторканність приватного життя. Основним правам тут треба протиставити обов'язок захищати інтереси дітей і їх право знати своїх батьків (ст. 39 Конституції). Якщо суд встановить необхідність такої експертизи, відповідач зобов’язаний підкоритися не тільки 3 огляду на свій обов'язок співпрацювати з правосуддям, а й 3 огляду на обов'язок піклуватися про своїх дітей.

У процедурі захисту не оспорюються норми, що мають силу закону, проте побічно у зв'язку з застосованим законом, «ущемлюють» права та свободи, може бути порушено подальшу процедуру щодо цього нормативного акта в пленарному засіданні КС за клопотанням палати, яка прийняла до розгляду скаргу (ст. 55.2). Крім того, на практиці КС допустив можливість оскарження дій приватних осіб, наприклад зняття з посад професорів за висловлення своєї думки або звільнення профспілкових діячів. Суд вказав, що якщо державний орган не вживає заходів у зв'язку з порушенням основних прав приватною особою, це порушення розцінюється як його власне (з практики ФРН).

КС зазначив, що контроль телекомунікацій, представляючи собою втручання у сферу приватного життя, недоторканність якої визнана Конституцією, має відповідати принципам законності та пропорційності. Згідно 3 останнім характер заходів, що вживаються, має бути обгрунтований вагою діяння і мають дотримуватися необхідні гарантії обгрунтованості відповідного судового рішення [9]. Отже, рішення має бути вмотивованим, бо воно є єдиним способом забезпечення прав захисту і визначення необхідної пропорційності обмеження основного права тих причин, за якими воно підлягає обмеженню. Тому це рішення не відповідає Конституції.

Приводом для розгляду справи про захист $є$ клопотання, в якому викладаються факти, на яких воно грунтується, вказуються порушені конституційні положення і необхідний захист із метою збереження або відновлення порушених прав (ст. 49). До нього додаються: 1) документ, що 
підтверджує повноваження представника; 2) у разі потреби, документ, що підтверджує завершення судової чи іншої процедури. Скарга і додані документи подаються з копіями в кількості, що відповідає числу осіб, які брали участь у судовому розгляді, плюс одна копія для прокуратури.

Конституційне судочинство є безплатним (ст. 95). КС може покласти судові витрати на одну або кілька сторін, які пред'явили необгрунтовані вимоги, якщо вважатиме, що це прояв неповаги до Суду або несумлінність. КС може накласти на заявників, які виявили неповагу до Суду або зловжили своїм правом, грошовий штраф.

Акти законодавчих органів підлягають попередньому оскарженню відповідно до їх внутрішніх правил. Решта звернень до КС можливі після вичерпання всіх способів судового захисту (ст. 43, 44) (принцип субсидіарності). Остання вимога належить і до оскарження рішень Національної ради 3 питань відмови від військової служби (ст. 1 Закону від 1984 N 8). Один із прикладів подібних справ - рішення від 28 листопада 1994 р. Заявник оскаржував судові рішення, що засуджують його до тюремного ув'язнення на термін 2 роки 4 місяці і 1 день за відмову від військової служби. Він стверджував, що порушено його право на свободу світогляду (ст. 16 Конституції), оскільки його пацифістські переконання суперечить проходженню не тільки військової, але і альтернативної соціальної служби. КС вирішив, що вказане право не є достатньою підставою для звільнення громадян із міркувань совісті від виконання встановлених обов'язків. Конституція визнає право на відмову з міркувань совісті, але тільки від військової служби. Здійснення цього права передбачає визнання обов'язку проходити альтернативну службу.

Існують додаткові критерії допустимості скарг на дії судових органів (ст. 44):
- в ході судового розгляду має бути зроблено посилання на порушене право відразу ж, як тільки стане про це відомо;

- порушення права або свободи має бути прямо і безпосередньо породжене дією або бездіяльністю судового органу, незалежно від фактичних обставин, на основі яких було розпочато провадження в цій справі і по суті яких КС не виносить ніякого рішення (під час розгляду звернень ампаро КС обмежується встановленням факту порушення прав заявника та їх захистом або відновленням і утримується від суджень про дії судових органів (ст. 54)).

Терміни оскарження порушень:

- звернення, предметом яких є рішення законодавчих органів, подаються протягом трьох місяців із дня закінчення їх оскарження згідно з внутрішніми актами цих органів (ст. 42);

- 20 днів із моменту повідомлення про судове рішення: а) для звернень, предметом яких є акти або дії виконавчих органів влади або посадових осіб (ст. 43.2); б) для звернень про захист права, порушеного діями або бездіяльністю судового органу (ст. 44.2).

На думку іспанських фахівців, настільки короткий термін для оскарження породжує велику кількість необгрунтованих клопотань. У 1988 р. щодо цих звернень введена процедура попереднього відбору. Щорічно в КС надходять понад 5000 скарг, тільки 4-5\% з них визнаються допустимими.

Якщо немає одностайності в процесі розгляду питання про прийнятність клопотання, Суд може заслухати заявника та прокуратуру, які мають право подати оформлення документів у (ст. 50.3), після чого в триденний термін виноситься мотивована ухвала щодо прийнятності звернення. Вмотивовані рішення, про які йдеться вище, не підлягають оскарженню. Суд сповіщає заявника про те, що протягом 10 днів він може виправити переборні недоліки клопотання (ст. 85.2). 
Якщо вони не будуть усунені у строк, виноситься невмотивована ухвала про неприйнятність звернення, яке не підлягає оскарженню.

Розподіл справ між палатами здійснюється Пленумом Суду за пропозицією його Голови (ст. 12). Пленум може розглянути сам будь-які справи, винесені на його розгляд Головою або трьома суддями (ст. $10.1(\mathrm{k}))$. Якщо палата вважає за необхідне відступити від правової позиції, раніше виробленої Судом, то вирішення цього питання також виноситься на Пленум Суду (ст. 13).

Після прийняття заяви Суд запитує в органа (представника влади), від якого виходили оспорюваний акт або дія, або суду, який проводив розгляд, необхідні документи (ст. 51). Дані особи направляють матеріали протягом 10 днів і вказують учасників попереднього процесу. Після отримання матеріалів і після закінчення терміну явки на розгляд палата знайомить із документами заявника осіб, які з'явилися, державного адвоката, якщо справа стосується публічної адміністрації, а також прокуратуру, яка бере участь у всіх процедурах ампаро 3 метою захисту законності, прав громадян та громадського інтересу, що охороняється законом (ст. 47.2, 52).

Відповідно до закону засідання Суду проводиться протягом 20 днів, в процесі надо вписать і його представляються необхідні аргументи в письмовій формі. У виняткових випадках (через завантаженість) палата з власної ініціативи або за клопотанням сторони може замінити письмову процедуру усним слуханням. Після заслуховування осіб, що з'явилися, Суд із власної ініціативи або на прохання сторони може з'єднати в одному провадженні справи, що стосуються одного предмета і вимагають єдиного рішення (ст. 83). Також Суд може вводити доказове виробництво на термін не більше 30 днів (ст. 89.1). На практиці з часу подачі клопотання до моменту винесення постанови проходить від трьох до п'яти років, і цей термін продовжує збільшуватися.

Палата має право призупинити з власної ініціативи або за клопотанням заявника виконання акта, що викликав звернення, якщо воно може завдати шкоди, який робить захист безпредметною (ст. 56). Клопотання про зупинення подається в будь-який час до прийняття рішення. Це питання розглядається 3 заслуховуванням сторін і прокуратури протягом трьох днів, у разі потреби - $з$ розглядом доповідної записки органів влади, що відповідають за виконання акта. Однак Суд може відмовити у призупиненні, якщо це здатне спричинити порушення загальних інтересів або прав і свобод третьої особи. Рішення про призупинення може бути змінено в процесіі розгляду (ст. 57).

Межі перевірки не обмежуються положеннями Конституції, а також включають норми міжнародного права. Наприклад, Європейська конвенція про захист прав людини і основних свобод, будучи частиною внутрішньої правової системи, має застосовуватися всіма судами. Якщо акт чи судове рішення порушує виключно зазначену Конвенцію, є допустимими скарги про скасування іï тлумачення, що суперечить конституційним положенням.

Після представлення аргументів або закінчення терміну розгляду палата виносить в 10-денний строк постанову (ст. 52.3), яка містить одне або кілька наступних положень:

1) оголошення недійсності акта, що перешкоджає реалізації прав і свобод, ыз визначенням, у разі потреби, сфери застосування цього положення;

2) публічне визнання права або свободи відповідно до його змістом, встановленим Конституцією;

3) відновлення в повному обсязі права чи свободи заявника і прийняття, у разі потреби, відповідних заходів для їх охорони (ст. 55). 
Судді можуть в окремій думці висловити свою, відмінну від загальної думки, позицію як із питання самого рішення, так і з питання його обгрунтування. Особливі думки включаються до постанов, які публікуються в «Офіційному віснику держави». КС виносить щорічно максимум 300 рішень за індивідуальними скаргами. Постанови набирають чинності з дня, наступного за днем опублікування. Вони не підлягають перегляду (п. 1 ст. 164 Конституціï). Однак протягом двох днів із дня повідомлення про рішення сторони можуть звернутися з проханням про їх роз'яснення (ст. 93.1). Суд може визначити у рішенні, хто має його виконати, а також домовитися про наслідки цього виконання (ст. 92). На будь-яку особу, яка не виконує приписів Суду в зазначені терміни, можуть накладатися штрафи або будь-яка інша форма відповідальності, яку Суд вважатиме необхідною (ст. 95.4). Клопотання про відшкодування шкоди, що розглядаються в процесі судових розглядів, мають бути представлені протягом одного року з дня опублікування рішення КС (ст. 58).

Висновки. На закінчення можна зазначити, що в процесі прийняття Закону про КС іспанський законодавець використовував положення Закону про КС Німеччини, тому процедура ампаро дуже нагадує німецький інститут конституційної скарги. Незважаючи на різницю в термінології, обидва звернення ініціюють конкретну форму конституційного контролю зі схожими процесами їх розгляду i являють собою важливий спосіб захисту громадян від порушень їніх основних прав і свобод.

\section{Список використаних джерел}

1. Шашкова А.В. Конституционное правосудие в Испании на примере процедуры ампаро. Право и государство: теория и практика. 2017. № 5 (149). С. 49-54.

2. Шашкова А.В. Правительство Испании (организационно-правовые проблемы) : дис. ... канд. юрид. наук. Москва, 2001. 162 с.

3. Шашкова А.В. Понятие механизма государственного управления. Высшие и центральные органы публичной администрации в Испании. Юрист. 1999. № 4. С. 6-12.

4. Шашкова А.В. Органы контроля за законностью в государственном управлении Испании. Президентский контроль. 1999. № 3. С. 33-39.

5. Constitucion Espanola, de 29 de diciembre de 1978.

6. Donini A., Forlivesi M., Rota A., Tullini P. Torwads collective protection for crowdworkers: Italy, Spain and France in the EU context. Transfer. 2017. № 23 (2). P. 207-223.

7. Hernandez R.M. Breach by the constitutional court of the fair administration of justice within the admission process of the recurso de amparo. The european court of human rights case arribas anton vs. Spain [Incumplimiento de la buena administracion de justicia del tribunal constitucional en la admision del recurso de amparo. El caso arribas anton vs. Espana del tedth]. Revista Espanola de Derecho Constitucional. 2016. P. 369-414.

8. Martinez M.A.A. El Recurso previo de in constitucionalidad segun la ley organica 12/2015: Un regreso esperado, una reforma insuficiente. Revista de Derecho Politico. 2015. № 97. P. 89-140.

9. Regionini G. Governmentalities without political capacity. Policy Sciences. 2017. № 50 (2). P. $163-178$.

10. Shashkova A.V., Rakittskaya I.A., Pavlov E.Ya. Emergence and Activity of Legal Entities in Russia in the PreRevolutionary Period (comparative analysis). Bylye Gody. 2017. Vol. 46. Is. 4. P. $1333-1344$.

11. Shashkova A.V. Study Manual on Bases of Russian Law. Cambridge Scholars Publishing. 2015. P. 374. 
Ірклієнко А. І. Процедура атраго в Конституційному суді Іспаніï: досвід для України

У статті здійснено дослідження процедурі атраго в Конституційному суді Іспанії. Встановлено, що в сучасній конституційно-правовій науці активно обговорюється питання запровадження в системі конституційного судочинства України інституту конституційної скарги як демократичного механізму захисту конституційних прав людини від посягань із боку держави та їі посадових осіб. Ця проблема неодмінно потрапляе в поле зору і під час офіційних заходів, які проходять у стінах Конституційного Суду України, та викликає підтримку з боку визнаних іноземних експертів. Резюмовано, що право на звернення до Конституційного суду з клопотанням про захист ампаро надано будь-якій фізичній або юридичній особі, Захиснику народу і прокуратурі (ст. 162.1 (в) Конституції, ст. 46 Закону). Якщо заява виходить від омбудсмена або прокуратури, то палата Конституційного суду, до відання якої належить розгляд справи, сповіщає про це відомих їй осіб, яких це звернення може торкнутися, та повідомляє про нього в «Офіційному віснику держави» (ст. 46.2).

Іноземні громадяни також мають право вимагати захисту в КС. Як приклад можна вказати рішення Конституційного суду від 12 лютого 1996 р. Фізичні та юридичні особи, які беруть участь у справі як сторони чи треті особи, мають доручити своє представництво в Конституційного суду судового повіреному і адвокату (ст. 81). Вимога не поширюється на громадян, які мають вищу юридичну освіту.

Узагальнено, що підстави звернення з клопотанням про захист обмежені. У більшості держав категорія природних прав збереглася на рівні доктринальних розробок, а в практиці Конституційного суду поступилася місцем позитивістському трактуванню прав і свобод. Тобто вони діють тільки в тому обсязі, в якому гарантуються конституцією і законами. Така позиція характерна і для Іспанії. Йдеться про порушення основних прав в їх класичному розумінні, тобто за винятком економічних і соціальних, у тому числі права власності. У практиці Європейського суду з прав людини зустрічаються справи за скаргами громадян Іспанії про втручання в їх зазначені права.

Ключові слова: скарга, Конституційний суд, права, адвокат, судовий повірений.

\section{Ирклиенко А. И. Процедура атраго в Конституционном суде Испании: опыт для Украины}

В статье проведено исследование процедуре атраго в Конституционном суде Испании. Установлено, что в современной конституционно-правовой науке активно обсуждается вопрос введения в системе конституционного судопроизводства Украины института конституционной жалобы как демократического механизма защиты конституционных прав человека от посягательств со стороны государства и его должностных лиц. Эта проблема непременно попадает в поле зрения и во время официальных мероприятий, которые проходят в стенах Конституционного Суда Украины, и вызывает поддержку со стороны признанных зарубежных экспертов. Резюмируется, что право на обращение в Конституционный суд с ходатайством о защите ампаро предоставлено любому физическому или юридическому лицу, защитнику народа и прокуратуре (ст. 162.1 (в) Конституции, ст. 46 Закона). Если заявление исходит от омбудсмена или прокуратуры, то палата Конституционного суда, к ведению которого относится рассмотрение дела, сообщает об этом известных ему лиц, кого данное обращение может коснуться, и сообщает о нем в «Официальном вестнике государства» (ст. 46.2).

Иностранные граждане также имеют право требовать защиты в КС. В качестве примера можно указать решение Конституционного суда от 12 февраля 1996 г. Физические и юридические лица, участвующие в деле в качестве сторон или третьих лиц, должны поручить свое представительство в Конституционный суд судебного поверенному и адвокату (ст. 81). Требование не распространяется на граждан, имеющих высшее юридическое образование. 
Основания обращения с ходатайством о защите ограничены. В большинстве государств категория естественных прав сохранилась на уровне доктринальных разработок, а в практике Конституционного суда уступила место позитивистской трактовке прав и свобод. То есть они действуют только в том объеме, в котором гарантируются конституцией и законами. Такая позиция характерна и для Испании. Речь идет о нарушении основных прав в их классическом понимании, то есть за исключением экономических и социальных, в том числе права собственности. В практике Европейского суда по правам человека встречаются дела по жалобам граждан Испании о вмешательстве в их указанные права.

Ключевъе слова: жалоба, Конституционный суд, права, адвокат, судебный поверенный.

Irkliienko A. The amparo procedure at the Constitutional Court of Spain: experience for Ukraine

The article has shown the results of the research of the amparo procedure at the Constitutional Court of Spain. It has been established that modern constitutional and legal science is actively discussing the issue of establishment of the institute of constitutional complaint into the system of constitutional justice of Ukraine as a democratic mechanism to protect constitutional human rights from infringement by the state and its officials. This problem inevitably gets in the crosshairs even during official events taking place within the walls of the Constitutional Court of Ukraine, and wins the support of recognized foreign experts. It has been summarized that the right to apply to the Constitutional Court with a request for protection of amparo is granted to any natural or legal person, the Defender of the People and the Prosecutor's Office (Article 162.1(c) of the Constitution, Article 46 of the Law). If the application comes from the ombudsman or the prosecutor's office, the chamber of the Constitutional Court, which is entitled to lead the case, notifies the persons known to them, who may be the matter of this appeal, and informs about it to "the Official Gazette" (Article 46.2).

Foreign citizens also have the right to demand protection in the Constitutional Court. It is possible to specify the example of the decision of the Constitutional Court dated 12th of February 1996. Natural and legal persons, involved in the case as parties or third parties, have to put their representation into charge of a court attorney and a lawyer at the Constitutional Court (Article 81). The requirement does not apply to citizens with law degree.

It has been generalized that the grounds for applying for protection are restricted. In most states, the category of natural rights has remained at the level of doctrinal deployments, and, in the practice of the Constitutional Court, it has given the way to a positivist interpretation of rights and freedoms. That is, they function only to that extent, which is guaranteed by the constitution and laws. Such a position is also characteristic for Spain. This refers to violation of fundamental rights in their classical notion, that is, with the exception of economic and social rights, including property rights. In the practice of the European Court of Human Rights, there are cases of complaints by the citizens of Spain concerning interference with their above-noted rights.

Key words: complaint, the Constitutional Court, rights, lawyer, court attorney. 